bioRxiv preprint doi: https://doi.org/10.1101/2021.10.21.465236; this version posted October 22, 2021. The copyright holder for this preprint (which was not certified by peer review) is the author/funder, who has granted bioRxiv a license to display the preprint in perpetuity. It is made available under aCC-BY 4.0 International license.

\title{
Microbial stowaways - waterbirds as dispersal vectors of aquatic pro- and microeukaryotic communities
}

\section{Running title: Microbial dispersal by waterbirds}

Beáta Szabón ${ }^{1}$ Attila Szabó1,2, Csaba F. $\operatorname{Vad}^{1,3,4}$, Emil Boros ${ }^{1}$, Dunja Lukić ${ }^{3,5}$, Robert Ptacnik $^{3}$, Zsuzsanna Márton ${ }^{1,3,6}, Z_{\text {sófia Horváth }}^{1,3,4}$

${ }^{1}$ Institute of Aquatic Ecology, Centre for Ecological Research, Budapest, Hungary

${ }^{2}$ Swedish University of Agricultural Sciences, Uppsala, Sweden

${ }^{3}$ WasserCluster Lunz - Biologische Station, Lunz am See, Austria

${ }^{4}$ Laboratory of Aquatic Ecology, Evolution and Conservation, KU Leuven, Leuven, Belgium

${ }^{5}$ Research Department for Limnology, University of Innsbruck, Mondsee, Austria

${ }^{6}$ Eötvös Loránd University, Budapest, Hungary

Correspondence

Beáta Szabó, Institute of Aquatic Ecology, Centre for Ecological Research, Budapest, Hungary

E-mail: schneiderbea@gmail.com

\section{Acknowledgements}

Authors thank the colleagues of Lake Neusiedl Biological Station, Thomas Zechmeister, Richard Haider and Rudolf Schalli, for their help in field work and providing us access to their labs; colleagues of Fertö-Hanság and Neusiedler See - Seewinkel National Parks for providing and helping us access the sites as part of the Vogelwarte - Madárvárta 2 project; Christian Preiler for further practical help; and Mia Bengtsson for her help with selecting the primers used in the study. The study was supported by the Interreg V-A Austria-Hungary programme of the European Regional Development Fund (Vogelwarte Madárvárta 2). BS acknowledges further support by NKFIH-132095. ZH and CFV were supported by GINOP 2.3.2.-15-201600057 and the AQUACOSM-plus project of the European Union's Horizon 2020 research and innovation programme under grant agreement No. 871081. ZH acknowledges support from the Janos Bolyai Research Scholarship of the Hungarian Academy of Sciences. AS was supported by the Wenner-Gren Foundations. BS, AS, CFV and ZH were furthermore supported by the NKFIH-471-3/2021 project.

\footnotetext{
Abstract

Aim: Waterbirds are important dispersal vectors of multicellular organisms such as macrophytes, aquatic macroinvertebrates, and zooplankton. However, no study to date has focused on their potential role in dispersing aquatic microbial communities. Here, we carried out the first explicit study on passive transport (endozoochory) of prokaryotes and unicellular microeukaryotes by waterbirds based on a metagenomic approach. By directly comparing the dispersed set of organisms to the source pool of a natural metacommunity, we aimed for a realistic estimate of the overall importance of waterbird zoochory for natural microbial communities.
} 
Location: Seewinkel region of Austria and Hungary.

Taxon: Prokaryotes and unicellular microeukaryotes.

Methods: In 2017 and 2018, water samples from natural aquatic habitats along with fresh droppings of the dominant greylag goose (Anser anser) and four other waterbird species were collected in a well-delineated habitat network of temporary saline ponds (soda pans). Their prokaryotic and microeukaryotic communities were identified via 16S and 18S rRNA gene amplicon sequencing and compared across years and waterbird species.

Results: We found that up to $40 \%$ of the dominant aquatic microbial OTUs were transported by $A$. anser. OTU richness in $A$. anser droppings was lower, but compositional variation was higher compared to the aquatic communities, probably resulting from stochastic pick-up of microbes from multiple aquatic habitats. We furthermore found that prokaryote species composition of bird droppings followed the interannual turnover in the aquatic communities. Finally, we found species-specific differences among different waterbird species. Among them, the planktivore filter-feeder northern shovelers (Anas clypeata) collected and dispersed a more species-rich subset of microeukaryotes than shorebirds or geese.

Main conclusions: Overall, our study provides the first quantitative empirical evidence of endozoochory in natural microorganism communities. These results imply that waterbirds may be crucial in maintaining ecological connectivity between discrete aquatic habitats at the level of microbial communities.

Keywords: aquatic microorganisms, bacteria, connectivity, dispersal, endozoochory, phytoplankton, protists, waterbirds 


\section{Introduction}

Dispersal is a key process connecting habitats, thereby sustaining gene flow (Clobert et al., 2012), biodiversity (Leibold et al., 2004), and ecosystem functions (Bannar-Martin et al., 2018; Zobel et al., 2006). For a long time, prokaryotes, together with unicellular and small multicellular eukaryotes have been considered to have a cosmopolitan distribution and their communities were assumed to be driven only by local environmental and biotic factors (BaasBecking, 1934; Beijerinck, 1913). However, recent studies (e.g. Cho \& Tiedje, 2000; Martiny et al., 2006; Telford et al., 2006; Zinger et al., 2014) benefiting from the rapid development of community sequencing methods led to a paradigm shift by providing evidence for biogeographical patterns and increased recognition of the importance of spatial processes in microorganisms (Langenheder \& Lindström, 2019; Mony et al., 2020; Ptacnik et al., 2010; van der Gast, 2015; Vyverman et al., 2007). This has finally placed microbes in the same metacommunity framework that has been already well-established for macroorganisms (Leibold \& Chase, 2018).

Hence, the importance of passive dispersal for microorganisms is now acknowledged, which can occur by wind (Genitsaris et al., 2011; Sharma et al., 2007), water currents (Luef et al., 2007), animals (Figuerola \& Green, 2002a; Green et al., 2008; Valls et al., 2017), and human activities (Reise et al., 1999; Ruiz et al., 2000). But despite the increasing interest in microbial dispersal and the availability of modern molecular techniques, zoochory is still largely neglected in this respect. Although there is evidence for waterbirds being effective short- and long-distance dispersal agents of macrophytes, macroinvertebrates, zooplankton and vertebrates (Brochet, Gauthier-Clerc, et al., 2010; Figuerola \& Green, 2002b; Figuerola et al., 2003; Lovas-Kiss et al., 2019, 2020; Reynolds \& Cumming, 2016; Silva et al., 2019; Viana et al., 2013a, 2013b), waterbird-mediated dispersal of unicellular microorganisms (especially bacteria) is poorly understood. There is only sporadic evidence for the transport of single and/or pathogen species via ecto- (Garmyn et al., 2012, Lewis et al., 2014) or endozoochory (Hartikainen et al., 2016, Jarma et al., 2021), while no explicit studies have so far targeted the dispersal potential of waterbirds for natural aquatic microbial communities with a direct comparison of natural communities to taxa dispersed by waterbirds.

Here, we present the first extensive study on the role of waterbirds as dispersal agents of aquatic pro- and eukaryotic unicellular microorganisms with the help of high-throughput DNA sequencing. Our study area was a landscape of saline temporary ponds, representing a well-delineated habitat network. The dominant waterbirds of the area (1,000-10,000 individuals depending on year and season, Boros, E., personal communication) are greylag geese (Anser anser), which are known to be regular large-bodied visitors of aquatic habitats, moving in flocks of up to 750 individuals (McKay et al., 2006). It has been suggested that they may contribute significantly to the transport of passively dispersing organisms across aquatic habitats (GarcíaÁlvarez et al., 2015; Green et al., 2002). However, we lack empirical data to assess their actual role as dispersal agents for microbial organisms.

In line with this, our main objective was to investigate the potential of zoochory by waterbirds for dispersing microorganisms among local habitats in a metacommunity. To this end, we compared the species pool of natural aquatic habitats with the metagenome found in bird droppings collected from the same habitat network. Specifically, our first aim was to reveal what proportion of the OTUs occurring in the aquatic habitats can be found in droppings of the dominant waterbird of the region, A. anser. Second, we tested whether community composition of the transported aquatic microbes is stable over time, i.e. reflects temporal changes in the natural aquatic communities. And finally, we assessed the dispersal potential of $A$. anser relative to four other waterbird species with different feeding habits and habitat use. 


\section{Material \& methods}

\section{Sampling and sample processing}

The study area ( $200 \mathrm{~km}^{2}$, Horváth et al., 2016) in the Seewinkel region of Austria and Hungary is characterized by a dense cluster of temporary saline ponds (soda pans). These habitats form a habitat network relatively isolated from freshwater habitats or other soda pans in the central and eastern regions of Hungary (Tóth et al., 2014). The clumped nature of this pondscape, with shallow ( $\leq 1 \mathrm{~m})$ and hypertrophic aquatic habitats (Boros et al., 2017) offers excellent feeding grounds for invertivorous waterbirds (Horváth et al., 2013) and breeding sites for several other species, including $~ 300$ pairs of greylag geese (Anser anser, Steiner \& ParzGollner, 2003). The region is legally protected as part of two national parks (NeusiedlerseeSeewinkel in Austria, and Fertő-Hanság in Hungary), designated as Important Bird Area (BirdLife International, 2021a, 2021b) and part of a UNESCO World Heritage site (Fertő / Neusiedlersee Cultural Landscape).

We collected samples from 25 soda pans in two consecutive years (3-6 April 2017 and 2-4 April 2018; Figure 1), representing all habitats that held water in both years (hereafter aquatic community samples). The sampled habitats are situated within $17 \mathrm{~km}$ (largest distance between two habitats), thereby representing a region where waterbirds can regularly move around on a daily basis (Bell, 1988, Boos et al., 2019; Link et al., 2011; Nilsson \& Persson, 1992). From each soda pan, a total of $20 \mathrm{~L}$ of water was collected from several points using a one-litre plastic beaker (thus collecting a pooled sample from the largest possible area) and sieved through a $100-\mu \mathrm{m}$ mesh plankton net to remove large zooplankton and filamentous algae which would hinder the detection of unicellular organisms during amplicon sequencing. For further processing, $1 \mathrm{~L}$ of this composite sieved water was immediately delivered to the laboratory in a glass bottle in a cool box. For molecular analysis, 1-50 mL of water (depending on turbidity, as Secchi depth ranged from 0.3 to $44 \mathrm{~cm}$ ) was filtered through a nitrocellulose membrane filter (Ø $47 \mathrm{~mm}$ ) with a pore size of $0.22 \mu \mathrm{m}$. Thereafter, filters were stored at -20 ${ }^{\circ} \mathrm{C}$ until DNA extraction.

Simultaneously, we collected fresh waterbird droppings at all sites that hosted a monospecific flock of waterbirds. We approached the birds roosting on dry mudflats or grasslands on the shores or right next to the soda pans and once they took off, fresh droppings were carefully collected in cryogenic vials, scraping off any soil or plant material and immediately frozen on dry ice. This way we avoided the potential contamination due to longterm exposure to e.g. wind-dispersed propagules. Bird droppings were stored at $-20{ }^{\circ} \mathrm{C}$ until further processing. In 2017, a total of 64 droppings from Anser anser, Calidris pugnax, Recurvirostra avosetta, Anas clypeata, while in 2018, altogether 70 droppings from A. anser and $A$. albifrons were collected with this method (Figure 1). The feeding mode of the waterbird species was summarized in Table S1.

\section{DNA isolation, amplification and sequencing}

DNA extraction from the filters and waterbird droppings was performed using the PowerSoil ${ }^{\circledR}$ DNA Isolation Kit (MO BIO Laboratories Inc., Carlsbad, CA, USA) following the manufacturer's instructions. Extracted DNA samples were stored at $-20{ }^{\circ} \mathrm{C}$ before shipping for amplification and sequencing at an external company (LGC Genomics, Berlin).

Prokaryotic 16S rRNA and microeukaryotic 18S rRNA gene amplification was carried out using the following primer pairs: EMBf 515F (GTGYCAGCMGCCGCGGTAA, Parada et al., 2016) - EMBr 806R (GGACTACNVGGGTWTCTAAT, Apprill et al., 2015) for the V4 
region of the prokaryotic 16S rRNA gene and UnivF-1183mod (AATTTGACTCAACRCGGG) - UnivR-1443mod (GRGCATCACAGACCTG) (Ray et al., 2016) for the V7 region of the eukaryotic 18S rRNA gene, elongated with sequencing barcodes and adapters. Amplification of the target taxonomic marker gene regions and sequencing were carried out by LGC Genomics (Berlin, Germany). The PCRs included about 1-10 ng of DNA extract (total volume $1 \mu \mathrm{l}$ ), $15 \mathrm{pmol}$ of each forward primer and reverse primer in $20 \mu \mathrm{L}$ volume of 1 x MyTaq buffer containing 1.5 units MyTaq DNA polymerase (Bioline $\mathrm{GmbH}$, Luckenwalde, Germany) and $2 \mu$ of BioStabII PCR Enhancer (Sigma-Aldrich Co.). Amplification was carried out for 30 cycles using the following parameters: 1 min $96^{\circ} \mathrm{C}$ predenaturation; $96{ }^{\circ} \mathrm{C}$ denaturation for $15 \mathrm{~s}, 55^{\circ} \mathrm{C}$ annealing for $30 \mathrm{~s}, 70{ }^{\circ} \mathrm{C}$ extension for $90 \mathrm{~s}$, hold at $8{ }^{\circ} \mathrm{C}$. The amplicon pools were purified with one volume Agencourt AMPure XP beads (Beckman Coulter, Inc., IN, USA) to remove primer dimer and other small mispriming products, followed by an additional purification on MiniElute columns (QIAGEN GmbH, Hilden, Germany). About 100 ng of each purified amplicon pool DNA was used to construct Illumina libraries using the Ovation Rapid DR Multiplex System 1-96 (NuGEN Technologies, Inc., CA, USA). Illumina libraries (Illumina, Inc., CA, USA) were pooled and size selected by preparative gel electrophoresis. Sequencing was performed on an Illumina MiSeq using $300 \mathrm{bp}$ paired-end format with a V3 Reagent Cartridge on the Illumina MiSeq platform, aiming for 50,000 raw sequence read pairs per sample.

\section{Amplicon data analysis}

Sequence processing, taxonomic assignments and OTU picking (at 99\% similarity level) were carried out with mothur v1.43.0 (Schloss et al., 2009) using the MiSeq SOP http://www.mothur.org/wiki/MiSeq_SOP (Kozich et al., 2013, downloaded at 12th November 2020). Additional quality filtering steps were also applied to eliminate possible sequence artefacts, such as the adjustment of the deltaq parameter to 10 in the 'make.contigs' command, primer removal from both ends of the sequences and the exclusion of singleton reads according to Kunin et al. (2010). Read alignment and taxonomic assignment were carried out using the ARB-SILVA SSU Ref NR 138 reference database with a minimum bootstrap confidence score of 80 (Quast et al., 2013). Reads assigned to non-primer-specific taxonomic groups ('Chloroplast', 'Mitochondria' and 'unknown') were subsequently removed from the dataset. For prokaryotic OTUs, the TaxAss software (Rohwer et al., 2018) with default parameters was used for taxonomic assignment with the FreshTrain (15 June 2020 release) and ARB-SILVA SSU Ref NR 138 databases, while taxonomic assignment of the 18S rRNA gene OTUs was performed using the PR2 v4.12.0 reference database (Guillou et al., 2013).

OTUs assigned to taxa Streptophyta, Metazoa, Ascomycota and Basidiomycota were omitted from the eukaryotic OTU set. Subsequently, both $16 \mathrm{~S}$ and $18 \mathrm{~S}$ datasets were rarefied to the read number of the sample having the lowest sequence count ( 8620 read per sample for the $16 \mathrm{~S}$ set and 2432 read per sample for the $18 \mathrm{~S}$ set).

\section{Statistical analysis}

We used the rarefied 16S (hereinafter referred to as prokaryotes) and 18S (microeukaryotes) community datasets separately in all our analyses. To exclude those organisms that might be exclusive for the gut microbiota of waterbirds, we only used OTUs that were present at least in one aquatic community sample with $\geq 1 \%$ relative abundance ("aquatic subset"). In the main part of the manuscript, we used only this aquatic subset. This subsetting was carried out separately for prokaryotes and microeukaryotes. The resulting aquatic subset of waterbird droppings contained $2.1 \%( \pm 4.3 \%)$ of the original prokaryotic and $5.4 \%( \pm 8.0 \%)$ of the microeukaryotic OTU abundances in these samples, whereas the subset of aquatic communities 
contained $72.0 \%( \pm 12.3 \%)$ of the original prokaryotic and $85.5 \%( \pm 8.1 \%)$ of the microeukaryotic OTU abundances detected in the unselected datasets.

For a quantitative assessment of waterbird dispersal potential in the pondscape, we only used $A$. anser samples, being the only species from which we could collect samples in both years. To exclude a potential bias arising from the different sampling effort in soda pans vs bird droppings, a random re-sampling was performed based on the lowest sample size for both prokaryotes $(n=21)$ and microeukaryotes $(n=9)$ per sample group, resulting in a total of 84 proand 36 microeukaryote samples used in these comparisons.

To test for differences in local ( $\alpha$-diversity) and regional OTU richness ( $\gamma$-diversity), together with the compositional change among samples (Whittaker's $\beta$-diversity: $\beta=\gamma / \alpha$ ) in the four sample groups (A. anser droppings and aquatic communities in 2017 and 2018), we used the permutation test of the 'mobr' package (McGlinn et al., 2021). Here, effect size $(\overline{\mathrm{D}})$ shows the average absolute difference between the four groups of samples and a $p$ value (based on 200 permutations) is calculated for each diversity level. To estimate the possible significant effect of sampling year and sample type, non-parametric Scheirer-Ray-Hare test with an interaction term was run using the 'rcompanion' package (Mangiafico, 2021), followed by Dunn's posthoc test for pairwise comparisons with 'FSA' package (Ogle et al., 2020) where p-values were adjusted with the Benjamini-Hochberg method.

We created stacked barplots to illustrate the quantitative differences of the higher-order prokaryotic and eukaryotic taxa among the sample groups. Prior to this, third level taxon names were assigned to the OTUs detected in the samples, thereafter OTU abundances belonging to the same taxon were summed up and expressed as relative abundance in each sample group.

Principal coordinate analysis (PCoA) was performed to illustrate the separation of samples according to sample type (A. anser droppings vs. aquatic communities) and sampling year (2017 vs. 2018) with the 'vegan' package (Oksanen et al., 2020). To test for significant differences in the same dataset, two-way PERMANOVA with an interaction term (based on 2000 permutations) was carried out, followed by a pairwise comparison of the four sample groups (based on 2000 permutations) with the 'pairwiseAdonis' package (Arbizu, 2017). We ran additional SIMPER analyses to determine which OTUs are the most responsible for the dissimilarities among sample types and sampling years. In order to provide comparable results, PCoA, PERMANOVA, pairwise comparison and SIMPER were all run based on Bray-Curtis dissimilarity calculated from OTU abundance data.

We repeated our analyses based on the unselected datasets (i.e. without selecting for aquatic taxa) and presented those results in the Supplementary material. To standardize sample sizes, re-sampling was carried out also for the unselected dataset of prokaryotes $(n=25)$ and microeukaryotes $(n=10)$ based on the lowest sample size resulting in a total of 100 pro- and 40 microeukaryote samples.

To compare prokaryotic and microeukaryotic OTU richness in each sample group (droppings of different waterbird species and aquatic community samples from both years), we applied sample-size-based rarefaction and extrapolation approach (Chao et al., 2014) using 'iNEXT' package (Hsieh et al., 2020). The 95\% confidence intervals were constructed by bootstrapping (based on 50 bootstrap replications).

To reveal if different waterbird species transport different microbial communities, and whether they differ among years, we performed separate PCoA analyses including all waterbird species from which samples were collected in at least one year (sample numbers after resampling the amplicon data are presented in Table S1). 
bioRxiv preprint doi: https://doi.org/10.1101/2021.10.21.465236; this version posted October 22, 2021. The copyright holder for this preprint (which was not certified by peer review) is the author/funder, who has granted bioRxiv a license to display the preprint in perpetuity. It is made available under aCC-BY 4.0 International license.

All analyses focusing on community composition were furthermore repeated for incidence data based on Sørensen dissimilarity.

Statistical analyses were carried out using R statistical software (R Core Team, 2020).

\section{Results}

We found a consistent difference between the number of prokaryotic and microeukaryotic OTUs in the two main sample types (Anser anser droppings and aquatic communities) after rarefaction. Local $(\alpha)$ and regional $(\gamma)$ OTU richness were significantly higher in the aquatic samples (in both years), while compositional variation ( $\beta$-diversity) was higher among the $A$. anser samples, especially in prokaryotes. There was no remarkable difference between the two sampling years (Figure 2, Table S2). When repeating the analyses for the unselected prokaryotic and microeukaryotic community datasets (thereby also including the gut microbiome and possible parasites of waterbirds), patterns of $\alpha$ - and $\gamma$-diversity were similar to the results based on the aquatic subset (i.e. less OTUs in $A$. anser samples independent of sampling year), however, $\beta$-diversity was low in case of both sample types in both years (Figure S1, Table S3).

In line with this, the majority of OTUs were found only in the aquatic habitats, with most OTUs shared between years (Figure 3, Venn diagrams). Even so, we detected a considerable proportion of OTUs present in aquatic habitats also in the A. anser samples: $40 \%$ of the prokaryotic and $21 \%$ of the microeukaryotic OTUs were shared among both types of samples, with $29-25 \%$ (prokaryotes) and $12-11 \%$ (microeukaryotes) of OTUs being shared among birds and aquatic communities within the same year (Figure 3). Among prokaryotes, $13 \%$ of the OTUs were found in all four sample groups (both sample types in both years; Figure 3). Compared to this, the share of microeukaryotic OTUs present in all four sample groups was low (3\%) (Figure 3). In the unselected community datasets, trends and differences were similar to those observed in our aquatic data subsets, except for the high number of OTUs unique to $A$. anser samples (31\% for prokaryotes and 24\% for microeukaryotes) (Figure S2).

At the level of major taxonomic units, all four sample groups were dominated by the same phylogenetic groups, both in prokaryotes and microeukaryotes (Figure 3). The most abundant prokaryotic taxa were Bacteroidia, Gammaproteobacteria, Alphaproteobacteria, Actinobacteria and Verrucomicrobiae, making up 77-95\% of the OTU abundances found in the aquatic communities and $61-93 \%$ in the A. anser samples. In microeukaryotes, Ochrophyta, Chlorophyta, and Fungi were similarly abundant, altogether representing 38-44\% of the OTU abundances in the aquatic samples and $34-84 \%$ in the $A$. anser droppings. There were also several groups that were abundant in the aquatic communities (both years) and in A. anser samples from at least one year, e.g. Haptophyta, Ciliophora and Cercozoa.

In prokaryotes, there was a marked interannual difference in the relative abundance of two taxonomic groups, Nitriliruptoria and Oxyphotobacteria. They were present in both the aquatic and $A$. anser samples with high proportions (9-30\% together) in 2017 and either missing completely (Oxyphotobacteria) or represented only with very low abundances $(\leq 0.6 \%)$ in 2018 (Figure 3).

Apart from these exceptions, all OTUs (both prokaryotic and microeukaryotic) that were mostly responsible for the differences between the sampling years and the sample types could be assigned to the higher-order taxa dominant in all or at least in one of the sample groups. Additionally, there was a considerable overlap between the OTUs responsible for the differences in both year and sample type (Table S4). 
Both prokaryotic and microeukaryotic samples showed a clear separation according to sample type (aquatic communities against $A$. anser droppings) and were less separated by year (Figure 4). This was in line with the stronger effect (indicated by higher $\mathrm{R}^{2}$ values) of sample type compared to year (though both were significant) based on PERMANOVA tests (Table 1). Pairwise comparisons of the four sample groups showed similar significant differences with overall higher $\mathrm{R}^{2}$ values for pairs of different sample types in prokaryotes, while in microeukaryotes the difference was significant only for the pairs of different sample types $(A$. anser or aquatic communities; Table 1). A following SIMPER analysis (Table S4) showed that the OTUs most responsible for these differences belonged to the dominant higher order taxa (Figure 3). The general patterns in the PCoA, PERMANOVA and pairwise comparisons repeated for the incidence and unselected data subsets were highly similar in both prokaryotes and microeukaryotes (Table S5-S6, Figure S3-S5).

We finally compared the richness (Figure 5, Figure S6) and composition (Figure S7S10) of microbes dispersed by the five waterbird species. Similar to the results based on rarefaction for A. anser droppings (Figure 2-3), only a fraction of the total species pool was recaptured in each waterbird species, but the actual proportion changed with species. Shorebirds (R. avosetta, C. pugnax) transported a similar fraction of microeukaryotic OTUs as geese $(A$. anser), both as individuals (mean richness) and collectively (the latter evidenced by regional extrapolated richness). Compared to them, A. clypeata proved to be much more efficient dispersal agents for microeukaryotes, dispersing almost twice as many OTUs as a same-sized group of any of the other species (Figure 5). Furthermore, we essentially found a similar number of OTUs per A. clypeata dropping as in a random aquatic sample (Figure 5). This also resulted in a clear separation of $A$. clypeata from the rest of the waterbirds on a PCoA ordination both with abundance- and incidence-based data (Figure S7-S8).

The comparison of waterbird species yielded somewhat different results for prokaryotes, where A. clypeata droppings no longer hosted significantly higher OTU richness than most of the other species (except for A. albifrons), and showed a large compositional overlap with communities dispersed by shorebirds ( $R$. avosetta, $C$. pugnax). In the two goose species, A. anser and A. albifrons, due to low read numbers for microeukaryotes we could only compare the composition of prokaryotes in their droppings, where the difference we found was negligible. While the overall composition of the dispersed set of prokaryotes was very similar among individual birds (Figure S7-S8), A. albifrons collectively transported a significantly lower diversity of OTUs: approximately only two thirds of those found in A. anser droppings (Figure 5).

In the unselected datasets, the prokaryotic and microeukaryotic communities transported by different bird species were much more distinct (Figure S9-S10), but even there, A. anser and A. albifrons samples showed high similarity.

\section{Discussion}

The main novelty of our study is twofold. First, it represents the first comprehensive study on the role waterbirds play in the dispersal of microorganisms based on a metagenomic approach targeting communities of prokaryotes and unicellular microeukaryotes, where we showed that waterbirds disperse all major aquatic groups from bacteria through phytoplankton to protozoa. Second, we directly compared microorganisms dispersed by waterbirds to the source pool (natural aquatic communities), thereby being able to investigate the share and identity of aquatic microbes readily transported by waterbirds. In this confined set of aquatic habitats (i.e. metacommunity), we indeed found a considerable share of aquatic communities dispersed by 
waterbirds (individuals of $A$. anser transported up to $40 \%$ of all aquatic OTUs detected in the study). Besides, the actual set of OTUs transported by the birds showed temporal changes in prokaryotes, reflecting the interannual turnover of aquatic communities, indicating that the dispersal potential of waterbirds depends on the actual aquatic communities. Finally, the communities transported by different waterbird species showed high similarities (regardless of their lifestyle), with a number of specific differences. The implications of our results showed minor sensitivity to the selection methods (unselected dataset or aquatic subset) or data type (abundance or incidence), and were largely consistent across prokaryotes and microeukaryotes. Altogether, our study provided the first explicit quantitative evidence clearly supporting that waterbirds are so far overlooked, yet potentially important dispersal agents of natural communities of aquatic microorganisms.

Prokaryotic and microeukaryotic communities of the aquatic subset were typical for soda lakes and pans of the region (Sinclair et al., 2015, Szabó et al., 2017, 2020). We found that more than one third of the prokaryotic and more than one fifth of the aquatic microeukaryotic OTUs were also present in the droppings of the dominant waterbirds species of the region, $A$. anser. Instead of dispersing a single or only a limited number of aquatic taxa, most of the major taxonomic groups of the aquatic communities were well-represented in the A. anser droppings. In waterbirds, gut retention time is short (Brochet, Guillemain, Gauthier-Clerc et al., 2010, Sánchez et al., 2012), which can contribute to a large share of undigested microorganisms. In extreme cases, even live plants (Silva et al., 2018), diatoms (Atkinson, 1971, 1980), aquatic invertebrates (Frisch et al., 2007; Green \& Sánchez, 2006) and gelatinous fish eggs (Lovas-Kiss et al., 2020) can survive waterbird gut passage. Compared to them, the survival of microorganisms should be even higher, given their evolutionary adaptations to adverse conditions such as extreme values of $\mathrm{pH}$, desiccation or UV radiation (Potts, 1999; Rainey et al., 2005; Schleper et al., 1995). Even though we did not test the viability of the detected microbes directly, these altogether make it highly likely that the OTUs we found included viable cells and hence indicate the possibility of successful dispersal events.

We found a significant interannual turnover of prokaryotic communities in the aquatic samples and in A. anser droppings. The shift in aquatic communities was also followed by the OTUs found in the droppings. This indicates that the set of dispersed prokaryotes reflects the natural microbial communities available in the local aquatic habitats at the given time. That is, our observations confirm the previous assumption that internal dispersal depends on the availability of aquatic (food) organisms (e.g. Brochet, Guillemain, Fritz, et al., 2010; Frisch et al., 2007), which can vary in time and is facilitated by the weak digestion efficiency mentioned above.

Even though $A$. anser do not feed directly from the water but rather consume seeds, stems and leaves of aquatic macrophytes and terrestrial plants (Middleton \& van der Valk, 1987), they can pick up microbes while drinking and while feeding on aquatic macrophytes or even while preening their damp feathers after bathing. Our results showed that this feeding mode still makes them efficient dispersal agents for aquatic microbial metacommunities. At the same time, we showed a high heterogeneity of prokaryotic and microeukaryotic OTU composition across bird droppings, indicating stochastic pickup by the individual birds. Although the difference in local and regional richness between droppings and aquatic communities was still remarkable, the compositional variation among droppings was moderated when $A$. anser gut microbiota was also considered, leading us to the conclusion that the gut microorganism composition of $A$. anser is specific to the species. This is in line with the findings of Laviad-Shitrit et al. (2019) that waterbird species host unique gut bacterial communities. 
We observed that not only $A$. anser but the other four bird species can also transport a considerable share of the natural microbial communities present in the ponds. While we found some differences between the waterbird species, these were not completely congruent with their feeding habits and habitat use. In spite of the terrestrial feeding habit of $A$. anser, the number of OTUs transported by them was largely comparable to those found in shorebirds, C. pugnax and $R$. avosetta, which prefer to feed in the shallow shoreline regions of ponds (Baccetti et al., 1998; Dietrich et al., 1997) and may directly consume biofilm communities as shown for multiple Calidris spp. (Kuwae et al., 2008, 2012). Even so, our results showed that they all disperse quite similar microeukaryotic communities across aquatic habitats.

The only species that showed marked differences from the rest of the waterbirds was $A$. clypeata. They not only transported different microeukaryotic communities but also captured a much larger fraction of the aquatic source pool, therefore they can be considered as the most effective dispersal agents. However, in terms of transporting prokaryotes, they were no longer so prominent. A reasonable explanation for our observations can be that $A$. clypeata, unlike the other waterbirds we studied, is a planktivore species sieving plankton from the open water (Matsubara et al., 1994). The low interlamellar distances in its specialized spoon-shaped bill enable an effective accumulation of aquatic microorganisms even smaller than $500 \mu \mathrm{m}$ (Gurd, 2007; Kooloos et al., 1989). Thus, microeukaryotes and their propagules of this size can be easily captured and concentrated, whereas bacterioplankton with a smaller size fraction probably flows through their lamellae.

When considering the dispersed prokaryotes, we did not find remarkable differences among the five bird species, neither in OTU richness, nor in composition. A. anser and $A$. albifrons transported quite similar prokaryotic communities and their gut microbiome also seems to be largely the same, which is not surprising given that both have a predominantly terrestrial herbivorous feeding habit (Ely \& Raveling, 2011; Middleton \& van der Valk, 1987). Nevertheless, of the two, A. anser hosted a higher number of OTUs in their droppings, which implies that it might have a more important role in the endozoochory of prokaryotes.

Our results are based on a representative comparison of equal sample sizes across aquatic habitats and bird droppings. We proved that within small-scale pond and lake networks $(10-20 \mathrm{~km})$, waterbirds can be important dispersal agents of both prokaryotes and microeukaryotes, given that the spatial scale of such pondscapes coincides with the local daily movements of waterbirds, including A. anser (Bell, 1988; Boos et al., 2019; Link et al., 2011; Nilsson \& Persson, 1992). As the study region might host up to hundreds of thousands of waterbirds (Dick et al., 1994), which themselves might defecate even up to 80 times per day (Oláh, 2003; Sterbetz, 1992), their overall contribution to biotic connectivity is expected to be immense, eventually being able to transport most members of the aquatic microbial metacommunity among the habitats.

The implications of this study are finally also important for larger spatial scales. According to their flight speed and gut retention times, waterbirds are able to transport their intestinal contents over thousands of kilometers during their migration (Viana et al., 2013a, 2013b, 2016), and therefore can be important dispersal agents of aquatic microorganisms not only on regional but even on continental scales. By dispersing microorganisms, they can have a significant role in forming biodiversity patterns and sustaining ecosystem functions where the importance of microbes is indisputable (Bell et al., 2005; Graham et al., 2016; Wohl et al., 2004). 
bioRxiv preprint doi: https://doi.org/10.1101/2021.10.21.465236; this version posted October 22, 2021. The copyright holder for this preprint (which was not certified by peer review) is the author/funder, who has granted bioRxiv a license to display the preprint in perpetuity. It is made available under aCC-BY 4.0 International license.

Table 1. Results of PERMANOVA and pairwise comparison performed on the aquatic subset (abundance data, Bray-Curtis dissimilarity; permutations=2000) of prokaryotic and microeukaryotic communities detected in aquatic community (AC) and Anser anser dropping samples in 2017 and 2018.

\begin{tabular}{|c|c|c|c|c|c|c|c|c|c|c|c|c|c|c|}
\hline \multirow[b]{2}{*}{ Factors } & \multicolumn{6}{|c|}{ Prokaryotes } & & \multicolumn{7}{|c|}{ Microeukaryotes } \\
\hline & Df & SS & MS & $\mathrm{F}$ & $\mathrm{R}^{2}$ & $\mathrm{p}$ & & Df & SS & MS & $\mathrm{F}$ & $\mathrm{R}^{2}$ & $\mathrm{p}$ & \\
\hline Sampling year & 1 & 1.234 & 1.234 & 3.439 & 0.034 & 0.0005 & $* * *$ & 1 & 0.599 & 0.599 & 1.391 & 0.037 & 0.0430 & $*$ \\
\hline Sample type & 1 & 5.035 & 5.035 & 14.026 & 0.139 & 0.0005 & *** $* *$ & 1 & 1.413 & 1.413 & 3.280 & 0.086 & 0.0005 & 冰泳 \\
\hline Sampling year*sample type & 1 & 1.106 & 1.107 & 3.082 & 0.031 & 0.0015 & $* *$ & 1 & 0.581 & 0.580 & 1.348 & 0.035 & 0.0505 & . \\
\hline Residuals & 80 & 28.719 & 0.359 & & 0.796 & & & 32 & 13.784 & 0.431 & & 0.842 & & \\
\hline Total & 83 & 36.095 & & & 1.000 & & & 35 & 16.376 & & & 1.000 & & \\
\hline Pairs & Df & SS & $\mathrm{F}$ & $\mathrm{R}^{2}$ & $\mathrm{p}_{\text {adj }}$ & & & Df & SS & $\mathrm{F}$ & $\mathrm{R}^{2}$ & padj & & \\
\hline 2017 A. anser $-2017 \mathrm{AC}$ & 1 & 2.736 & 7.291 & 0.154 & 0.0030 & $* *$ & & 1 & 1.176 & 2.879 & 0.152 & 0.0030 & *** & \\
\hline $2017 \mathrm{~A}$. anser $-2018 \mathrm{~A}$. anser & 1 & 1.143 & 2.747 & 0.064 & 0.0030 & $* *$ & & 1 & 0.646 & 1.463 & 0.084 & 0.1979 & $\mathrm{~ns}$ & \\
\hline 2017 A. anser $-2018 \mathrm{AC}$ & 1 & 3.513 & 10.325 & 0.205 & 0.0030 & $* *$ & & 1 & 1.140 & 2.759 & 0.147 & 0.0030 & *** & \\
\hline 2017 AC - 2018 A. anser & 1 & 2.756 & 7.298 & 0.154 & 0.0030 & $* *$ & & 1 & 0.873 & 1.946 & 0.108 & 0.0060 & ** & \\
\hline $2017 \mathrm{AC}-2018 \mathrm{AC}$ & 1 & 1.198 & 3.968 & 0.090 & 0.0030 & $* *$ & & 1 & 0.534 & 1.271 & 0.074 & 1.0000 & ns & \\
\hline 2018 A. anser $-2018 \mathrm{AC}$ & 1 & 3.405 & 9.936 & 0.199 & 0.0030 & *** & & 1 & 0.818 & 1.805 & 0.101 & 0.0030 & *** & \\
\hline
\end{tabular}


bioRxiv preprint doi: https://doi org/10.1101/2021 10.21.465236; this version posted October 22, 2021. The copyright holder for this preprint (which was not certified by peer review) is the author/funder, who has granted bioRxiv a license to display the preprint in perpetuity. It is made available under aCC-BY 4.0 International license.

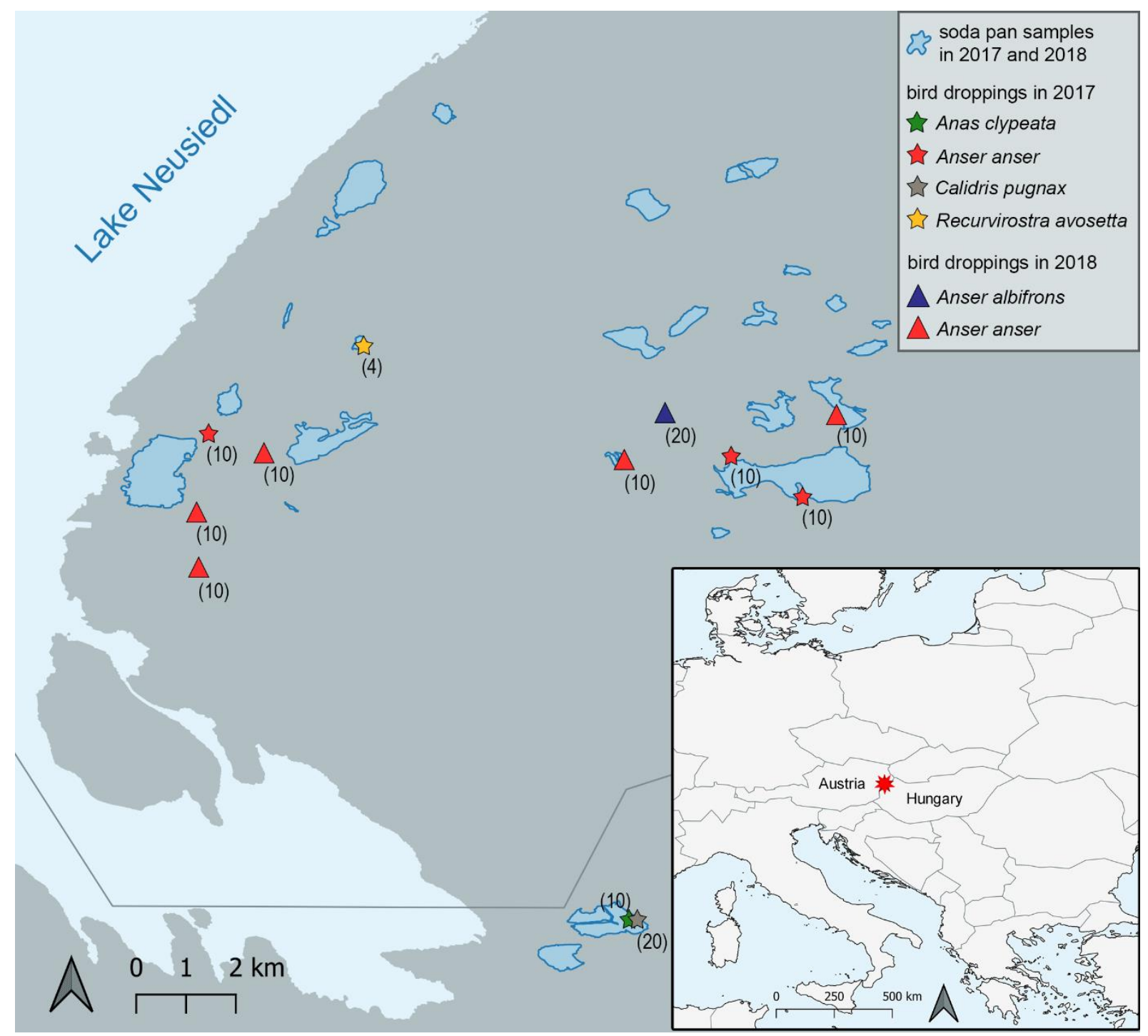

Figure 1. Map of the region and the sampling sites. The number of collected samples is indicated in brackets. 


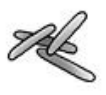

a-diversity

$\bar{D}=69.58 \mathrm{p}=0.005$

Prokaryotes
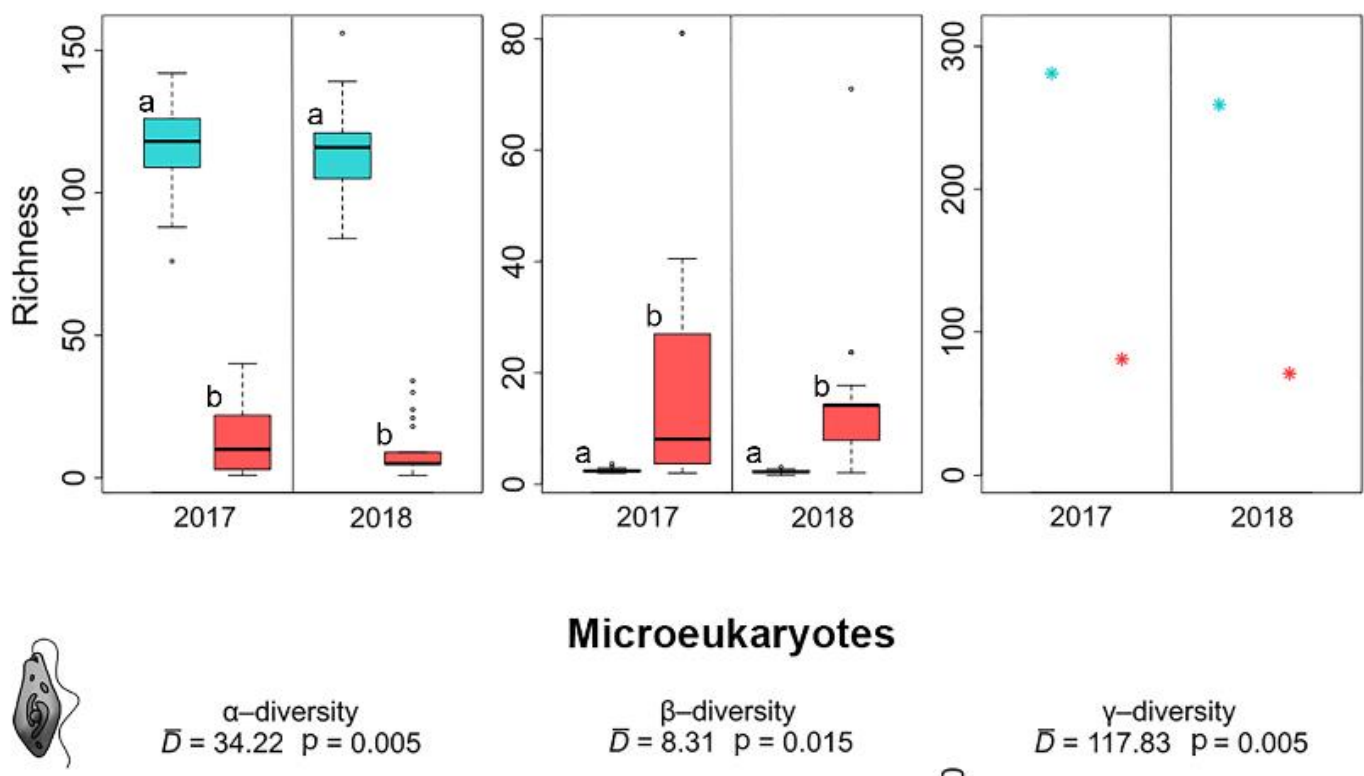

$$
\begin{gathered}
\text { a-diversity } \\
\bar{D}=34.22 \quad \mathrm{p}=0.005
\end{gathered}
$$
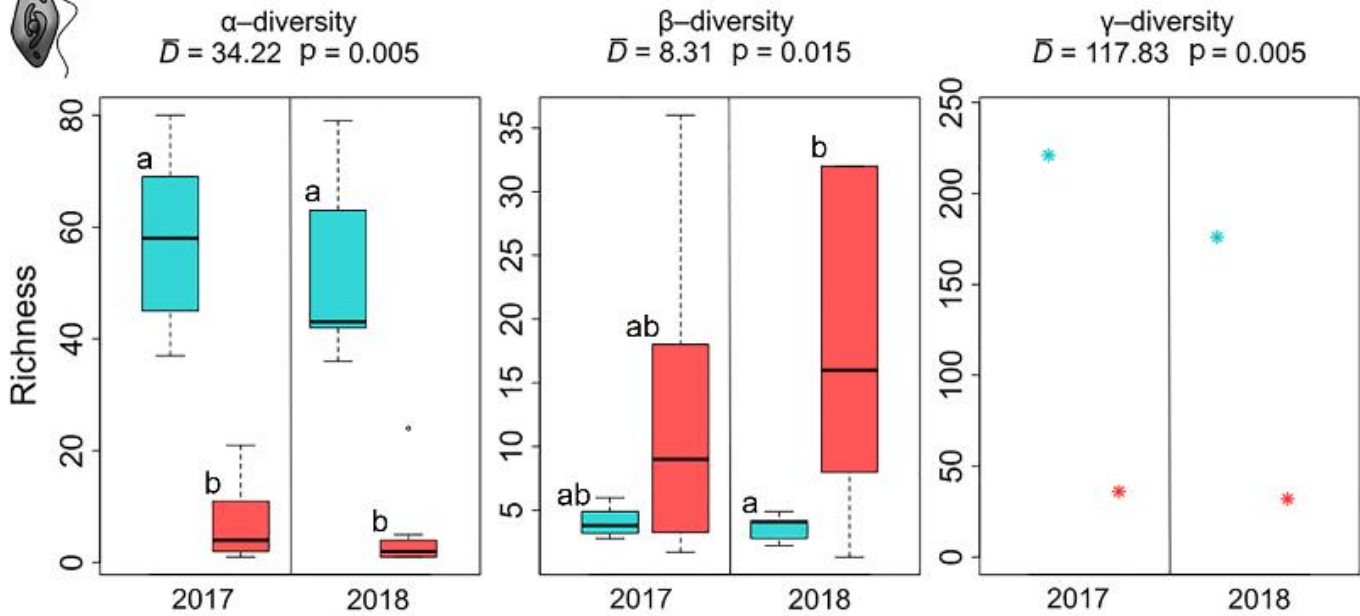

Sample type

Aquatic community

Anser anser

Figure 2. $\alpha$-, $\beta$ - and $\gamma$-diversity of the prokaryotic and microeukaryotic aquatic subsets in aquatic communities and Anser anser droppings in 2017 and 2018. $\bar{D}$ (effect size) indicates the average absolute difference between the four sample groups, p-value (permutations=200) indicates the significance of the overall group effect. Different letters indicate statistically significant differences at a significant level of $p_{a d j}<0.05$ based on Dunn's pairwise post-hoc test. Pairwise gamma diversity comparisons are presented in Figure 5. 


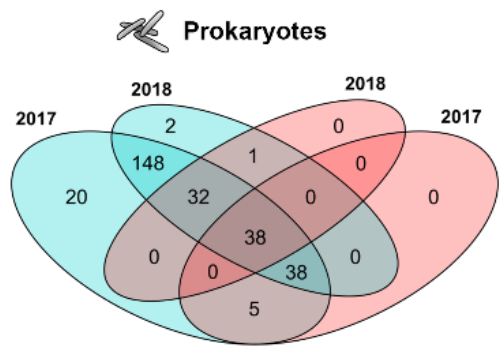

Sample type
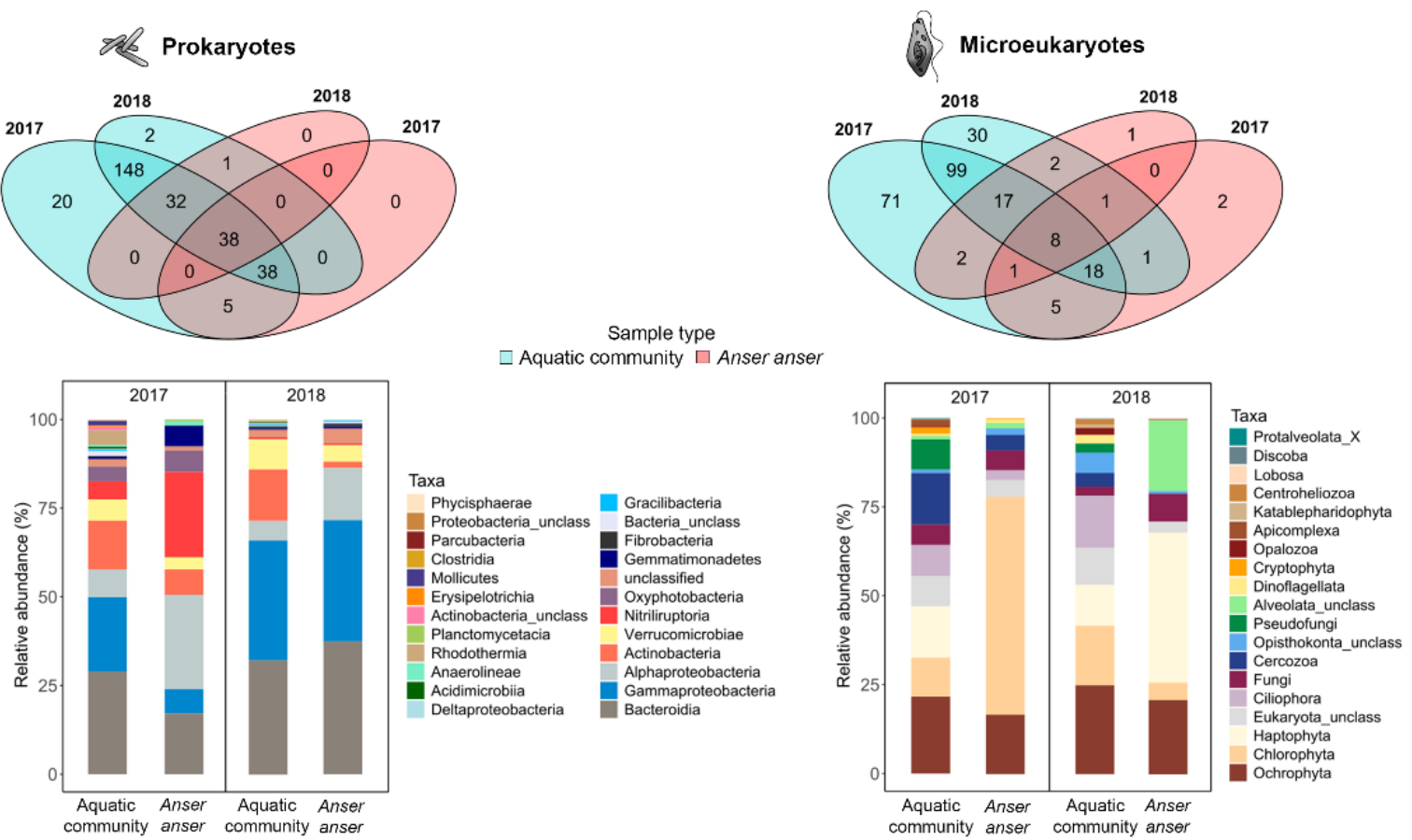

Figure 3. Number of prokaryotic and microeukaryotic OTUs (above) shared among sample types (aquatic community and Anser anser dropping) and years, and the relative abundance of higher-order taxa (below) in the aquatic subsets. 

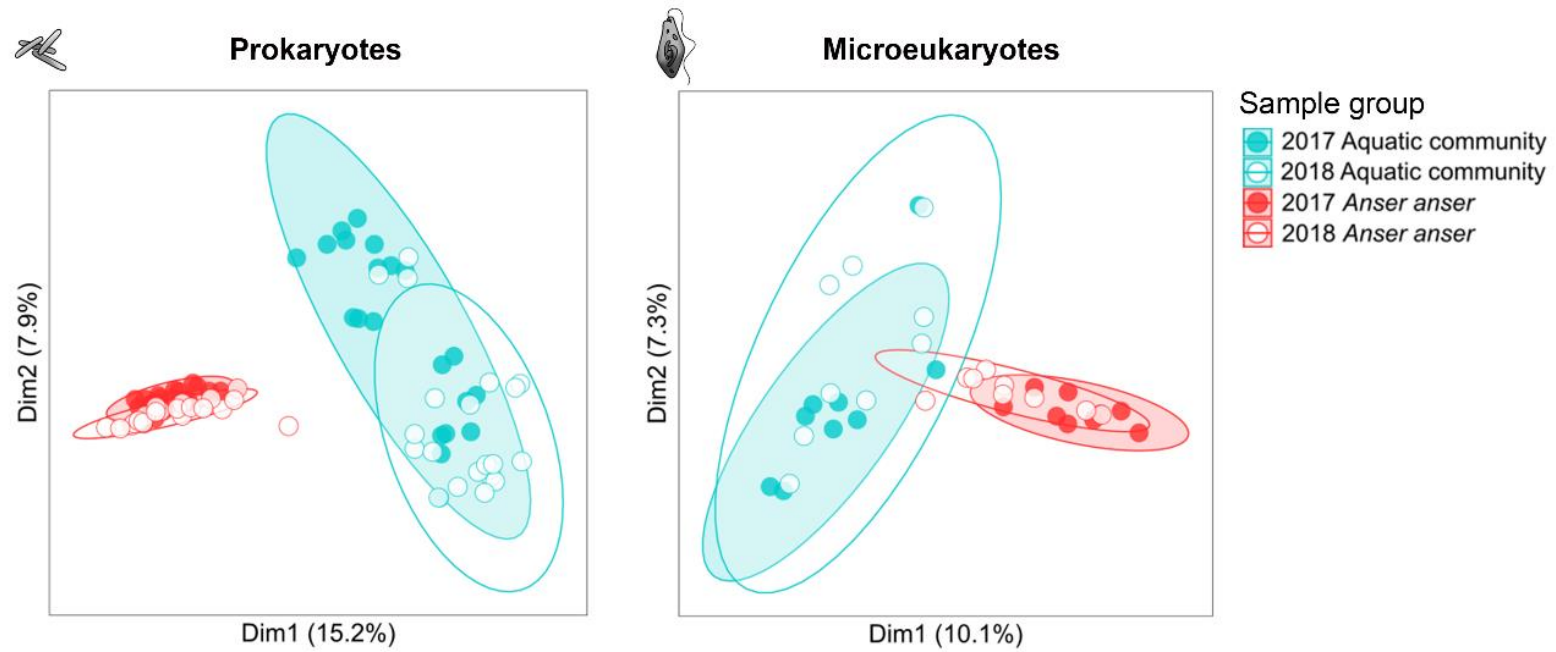

Figure 4. PCoA biplot of aquatic community and Anser anser dropping samples collected in 2017 and 2018. The analysis is based on the aquatic subset (abundance data, Bray-Curtis dissimilarity) of prokaryotic and microeukaryotic communities. 

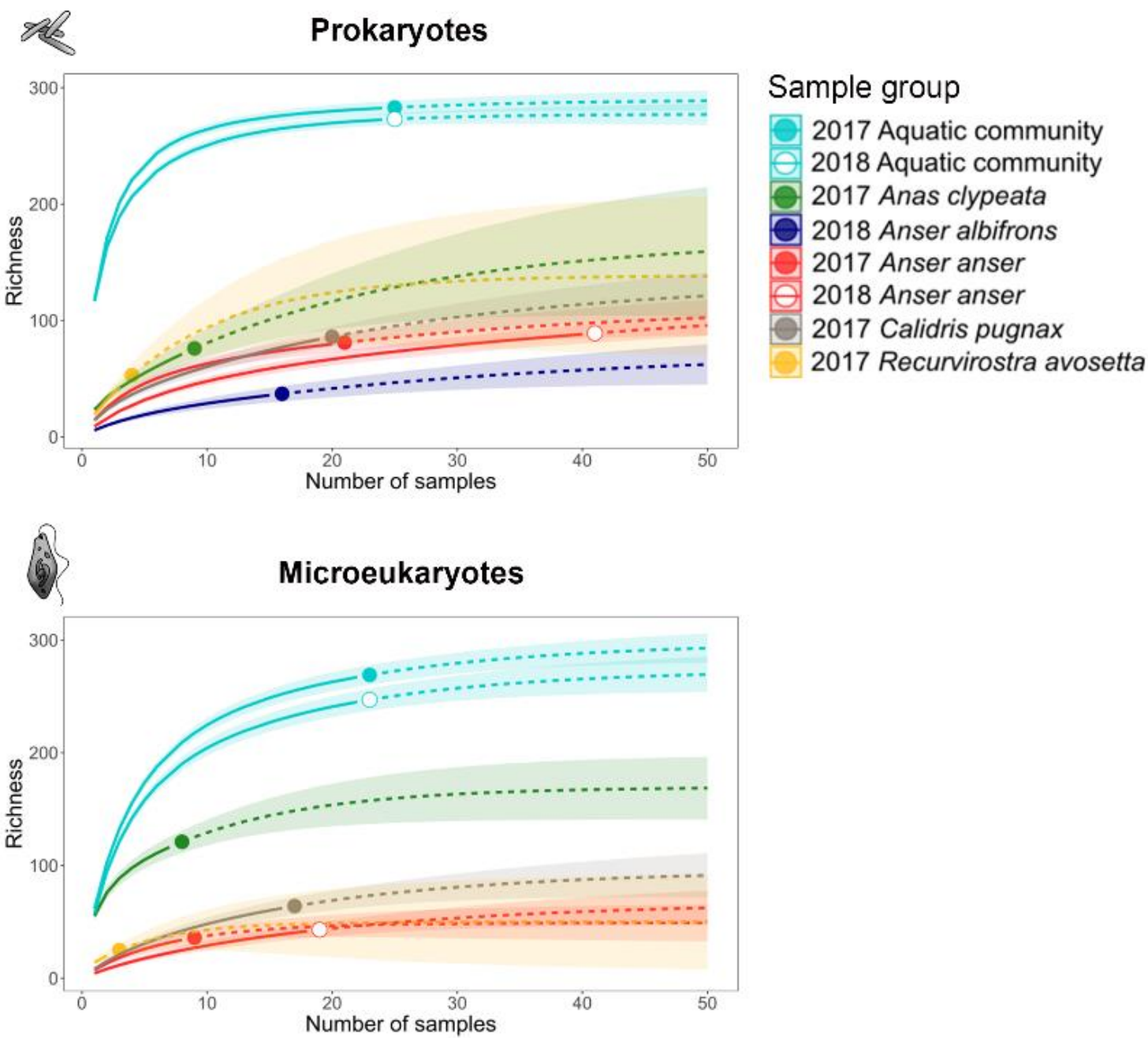

Figure 5. OTU accumulation curves with extrapolated richness estimates and confidence intervals for the aquatic subsets of prokaryotes and microeukaryotes dispersed by the five waterbird species compared to the aquatic communities. 
bioRxiv preprint doi: https://doi org/10.1101/2021.10.21.465236; this version posted October 22, 2021. The copyright holder for this preprint (which was not certified by peer review) is the author/funder, who has granted bioRxiv a license to display the preprint in perpetuity. It is made available under aCC-BY 4.0 International license.

\section{Data availability statement}

Raw sequence reads were deposited in the NCBI SRA database and are accessible through the BioProject accession PRJNA748202. 


\section{References}

Apprill, A., McNally, S., Parsons, R., \& Weber, L. (2015). Minor revision to V4 region SSU rRNA 806R gene primer greatly increases detection of SAR11 bacterioplankton. Aquatic Microbial Ecology, 75, 129-137. https://doi.org/10.3354/ame01753

Arbizu, P. M. (2017). pairwiseAdonis: Pairwise Multilevel Comparison using Adonis. - R package version 0.0.1. https://github.com/pmartinezarbizu/pairwiseAdonis

Atkinson, K. M. (1971). Further experiments in dispersal of phytoplankton by birds. Wildfowl, 22, 98-99.

Atkinson, K. M. (1980). Experiments in dispersal of phytoplankton by ducks. British Phycological Journal, 15, 49-58. https://doi.org/10.1080/00071618000650061

Baas-Becking, L. G. M. (1934). Geobiologie of inleiding tot de milieukunde. W. P. Van Stockum and Zoon, The Hague.

Baccetti, N., Chelazzi, L., Colombini, I., \& Serra, L. (1998). Preliminary data on the diet of migrating ruffs Philomachus pugnax in northern Italy. International Wader Studies, 10, 361364.

Bannar-Martin, K. H., Kremer, C. T., Ernest, S. M., Leibold, M. A., Auge, H., Chase, J., ... Supp, S. R. (2018). Integrating community assembly and biodiversity to better understand ecosystem function: the Community Assembly and the Functioning of Ecosystems (CAFE) approach. Ecology Letters, 21, 167-180. https://doi.org/10.1111/ele.12895

Beijerinck, M. W. (1913). De infusies en de ontdekking der backteriën. Jaarboek van de Koninklijke Akademie voor Wetenschappen. Amsterdam, Johannes Müller.

Bell, M. V. (1988). Feeding behaviour of wintering pink-footed and greylag geese in north-east Scotland. Wildfowl, 39, 43-53.

Bell, T., Newman, J. A., Silverman, B. W., Turner, S. L., \& Lilley, A. K. (2005). The contribution of species richness and composition to bacterial services. Nature, 436, 1157-1160. https://doi.org/10.1038/nature03891

BirdLife International (2021a). Important Bird Areas factsheet: Lake Fertö.

BirdLife International (2021b). Important Bird Areas factsheet: Southern Seewinkel and Zitzmannsdorfer Wiesen.

Boos, M., Nesterova, A. P., Chevallier, D., \& Follestad, A. (2019). Migratory flights and local wintering movements of greylag geese Anser anser in western Europe. Bird Study, 66(2), 264268. https://doi.org/10.1080/00063657.2019.1620171

Boros, E., V.-Balogh, K., Vörös, L., \& Horváth, Z. (2017). Multiple extreme environmental conditions of intermittent soda pans in the Carpathian Basin (Central Europe). Limnologica, 62, 38-46. https://doi.org/10.1016/j.limno.2016.10.003

Brochet, A. L., Guillemain, M., Gauthier-Clerc, M., Fritz, H., \& Green, A. J. (2010). Endozoochory of Mediterranean aquatic plant seeds by teal after a period of desiccation: Determinants of seed survival and influence of retention time on germinability and viability. Aquatic Botany, 93(2), 99-106. https://doi.org/10.1016/j.aquabot.2010.04.001 
Brochet, A. L., Gauthier-Clerc, M., Guillemain, M., Fritz, H., Waterkeyn, A., Baltanás, Á., \& Green, A. J. (2010). Field evidence of dispersal of branchiopods, ostracods and bryozoans by teal (Anas crecca) in the Camargue (southern France). Hydrobiologia, 637, 255-261. https://doi.org/10.1007/s10750-009-9975-6

Brochet, A. L., Guillemain, M., Fritz, H., Gauthier-Clerc, M., \& Green, A. J. (2010). Plant dispersal by teal (Anas crecca) in the Camargue: duck guts are more important than their feet. Freshwater Biology, 55(6), 1262-1273. https://doi.org/10.1111/j.1365-2427.2009.02350.x

Chao, A., Gotelli, N. J., Hsieh, T. C., Sander, E. L., Ma, K. H., Colwell, R. K., \& Ellison, A. M. (2014). Rarefaction and extrapolation with Hill numbers: a framework for sampling and estimation in species diversity studies. Ecological Monographs, 84, 45-67. https://doi.org/10.1890/13-0133.1

Cho, J.-C., \& Tiedje, J. M. (2000). Biogeography and degree of endicity of fluorescent Pseudomonas strains in soil. Applied and Environmental Microbiology, 66(12), 5448-5456. https://doi.org/10.1128/AEM.66.12.5448-5456.2000

Clobert, J., Baguette, M., Benton, T. G., \& Bullock, J. M. (2012). Dispersal ecology and evolution. Oxford University Press.

Dick, G., Dvorak, M., Grüll, A., Kohler, B., \& Rauer, G. (1994). Vogelparadies mit Zukunft? Ramsar-Bericht 3 Neusiedler See - Seewinkel. Umweltbundesamt, Wien.

Dietrich, S., Büthe, A., Denker, E., \& Hötker, H. (1997). Organochlorines in eggs and food organisms of avocets (Recurvirostra avosetta). Bulletin of Environmental Contamination and Toxicology, 58, 219-226. https://doi.org/10.1007/s001289900323

Ely, C., \& Raveling, D. G. (2011). Seasonal variation in nutritional characteristics of the diet of greater white-fronted geese. The Journal of Wildlife Management, 75(1), 78-91. https://doi.org/10.1002/jwmg.13

Figuerola, J., \& Green, A. J. (2002a). Dispersal of aquatic organisms by waterbirds: a review of past research and priorities for future studies. Freshwater Biology, 47, 483-494. https://doi.org/10.1046/j.1365-2427.2002.00829.x

Figuerola, J., \& Green, A. J. (2002b). How frequent is external transport of seeds and invertebrate eggs by waterbirds? A study in Doñana, SW Spain. Archiv für Hydrobiologie, 155, 557-565. https://doi.org/10.1127/archiv-hydrobiol/155/2002/557

Figuerola, J., Green, A. J., \& Santamaría, L. (2003). Passive internal transport of aquatic organisms by waterfowl in Doñana, south-west Spain. Global Ecology and Biogeography, 12, 427-436. https://doi.org/10.1046/j.1466-822X.2003.00043.x

Frisch, D., Green, A. J., \& Figuerola, J. (2007). High dispersal capacity of a broad spectrum of aquatic invertebrates via waterbirds. Aquatic Sciences, 69(4), 568-574. https://doi.org/10.1007/s00027-007-0915-0

García-Álvarez, A., van Leeuwen, C. H. A., Luque, C. J., Hussner, A., Vélez-Martín, A., PérezVázquez, A., ... Castellanos, E. M. (2015). Internal transport of alien and native plants by geese and ducks: an experimental study. Freshwater Biology, 60, 1316-1329. https://doi.org/10.1111/fwb.12567 
Garmyn, A., Van Rooij, P., Pasmans, F., Hellebuyck, T., Van Den Broeck, W., Haesebrouck, F., \& Martel. A. (2012). Waterfowl: potential environmental reservoirs of the chytrid fungus Batrachochytrium dendrobatidis. PLoS One, 7(4), e35038. https://doi.org/10.1371/journal.pone.0035038

Genitsaris, S., Moustaka-Gouni, M., \& Kormas, K. A. (2011). Airborne microeukaryote colonists in experimental water containers: diversity, succession, life histories and established food webs. Aquatic Microbial Ecology, 62, 139-152. https://doi.org/10.3354/ame01463

Graham, E. B., Knelman, J. E., Schindlbacher, A., Siciliano, S., Breulmann, M., Yannarell, A., ... Nemergut, D. R. (2016). Microbes as engines of ecosystem function: When does community structure enhance predictions of ecosystem processes? Frontiers in Microbiology, 7, 214. https://doi.org/10.3389/fmicb.2016.00214

Green, A. J., Figuerola, J., \& Sánchez, M. I. (2002). Implications of waterbird ecology for the dispersal of aquatic organisms. Acta Oecologica, 23(3), 177-189. https://doi.org/10.1016/S1146-609X(02)01149-9

Green, A. J., Jenkins, K. M., Bell, D., Morris, P. J., \& Kingsford, R. T. (2008). The potential role of waterbirds in dispersing invertebrates and plants in arid Australia. Freshwater Biology, 53(2), 380-392. https://doi.org/10.1111/j.1365-2427.2007.01901.x

Green, A. J., \& Sánchez, M. I. (2006). Passive internal dispersal of insect larvae by migratory birds. Biology Letters, 2, 55-57. https://doi.org/10.1098/rsbl.2005.0413

Guillou, L., Bachar, D., Audic, S., Bass, D., Berney, C., Bittner, L., ... Christen, R. (2013). The Protist Ribosomal Reference database $\left(\mathrm{PR}^{2}\right)$ : a catalog of unicellular eukaryote Small Sub-Unit rRNA sequences with curated taxonomy. Nucleic Acids Research, 41, D597-D604. https://doi.org/10.1093/nar/gks1160

Gurd, D. B. (2007). Predicting resource partitioning and community organization of filterfeeding dabbling ducks from functional morphology. The American Naturalist, 169(3), 334343. https://doi.org/10.1086/510924

Hartikainen, H., Bass, D., Briscoe, A. G., Knipe, H., Green, A. J., \& Okamura, B. (2016). Assessing myxozoan presence and diversity using environmental DNA. International Journal for Parasitology, 46(12), 781-792. https://doi.org/10.1016/j.ijpara.2016.07.006

Horváth, Z., Vad, C. F., Vörös, L., \& Boros, E. (2013). The keystone role of anostracans and copepods in European soda pans during the spring migration of waterbirds. Freshwater Biology, 58(2), 430-440. https://doi.org/10.1111/fwb.12071

Horváth, Z., Vad, C. F., \& Ptacnik, R. (2016). Wind dispersal results in a gradient of dispersal limitation and environmental match among discrete aquatic habitats. Ecography, 39, 726-732. https://doi.org/10.1111/ecog.01685

Hsieh, T. C., Ma, K. H., \& Chao, A. (2020). iNEXT: Interpolation and Extrapolation for Species Diversity. R package version 2.0.20. https://CRAN.R-project.org/package=iNEXT

Jarma, D., Sánchez, M. I., Green, A. J., Peralta-Sánchez, J. M., Hortas, F., Sánchez-Melsió, A., \& Borrego, C. M. (2021). Faecal microbiota and antibiotic resistance genes in migratory 
waterbirds with contrasting habitat use. Science of The Total Environment, 783, 146872. https://doi.org/10.1016/j.scitotenv.2021.146872

Kooloos, J. G. M., Kraaijeveld, A. R., Langenbach, G. E. J., \& Zweers, G. A. (1989). Comparative mechanics of filter feeding in Arias platyrhynchos, Anas clypeata and Aythya fuligula (Ayes, Anseriformes). Zoomorphology, 108, 269-290. https://doi.org/10.1007/BF00312160

Kozich, J. J., Westcott, S. L., Baxter, N. T., Highlander, S. K., \& Schloss, P. D. (2013). Development of a dual-index sequencing strategy and curation pipeline for analyzing amplicon sequence data on the MiSeq Illumina sequencing platform. Applied and Environmental Microbiology, 79(17), 5112-20. https://doi.org/10.1128/AEM.01043-13

Kunin, V., Engelbrektson, A., Ochman, H., \& Hugenholtz, P. (2010). Wrinkles in the rare biosphere: pyrosequencing errors can lead to artificial inflation of diversity estimates. Environmental Microbiology, 12, 118-23. https://doi.org/10.1111/j.1462-2920.2009.02051.X

Kuwae, T., Beninger, P. G., Decottignies, P., Mathot, K. J., Lund, D. R., \& Elner, R. W. (2008). Biofilm grazing in a higher vertebrate: the western sandpiper, Calidris mauri. Ecology, 89(3), 599-606. https://doi.org/10.1890/07-1442.1

Kuwae, T., Miyoshi, E., Hosokawa, S., Ichimi, K., Hosoya, J., Amano, T., ... Elner, R.W. (2012). Variable and complex food web structures revealed by exploring missing trophic links between birds and biofilm. Ecology Letters, 15(4), 347-356. https://doi.org/10.1111/j.14610248.2012.01744.x

Langenheder, S., \& Lindström, E. S. (2019). Factors influencing aquatic and terrestrial bacterial community assembly. Environmental Microbiology Reports, 11, 306-315. https://doi.org/10.1111/1758-2229.12731

Laviad-Shitrit, S., Izhaki, I., Lalzar, M., \& Halpern, M. (2019). Comparative Analysis of Intestine Microbiota of Four Wild Waterbird Species. F, 10, 1911. https://doi.org/10.3389/fmicb.2019.01911rontiers in Microbiology

Leibold, M. A., \& Chase, J. M. (2018). Metacommunity Ecology. Monographs in population biology (Vol. 59). Princeton University Press.

Leibold, M. A., Holyoak, M., Mouquet, N., Amarasekare, P., Chase, J. M., Hoopes, M. F., ... Gonzalez, A. (2004). The metacommunity concept: a framework for multi-scale community ecology. Ecology Letters, 7, 601-613. https://doi.org/10.1111/j.1461-0248.2004.00608.x

Lewis, L. R., Behling, E., Gousse, H., Qian, E., Elphick, C. S., Lamarre, J., ... Goffinet B. (2014). First evidence of bryophyte diaspores in the plumage of transequatorial migrant birds. PeerJ, 2, e424. https://doi.org/10.7717/peerj.424

Link, P., Afton, A. D., Cox, R. R., \& Davis, B. E. (2011). Daily movements of female mallards wintering in Southwestern Louisiana. Waterbirds, 34(4), 422-428. https://doi.org/10.1675/063.034.0404

Lovas-Kiss, Á., Sánchez, M. I., Wilkinson, D. M., Coughlan, N. E., Alves, J. A., \& Green, A. J. (2019). Shorebirds as important vectors for plant dispersal in Europe. Ecography, 42, 956967. https://doi.org/10.1111/ecog.04065

Lovas-Kiss, Á., Vincze, O., Löki, V., Pallér-Kapusi, F., Halasi-Kovács, B., Kovács, G., ... Lukács, B. A. (2020). Experimental evidence of dispersal of invasive cyprinid eggs inside 
migratory waterfowl. Proceedings of the National Academy of Sciences, 17(27), 15397-15399. https://doi.org/10.1073/pnas.2004805117

Luef, B., Aspetsberger, F., Hein, T., Huber, F., \& Peduzzi, P. (2007). Impact of hydrology on free-living and particle-associated microorganisms in a river floodplain system (Danube, Austria). Freshwater Biology, 52, 1043-1057. https://doi.org/10.1111/j.13652427.2007.01752.x

Mangiafico, S. S. (2021). rcompanion: Functions to Support Extension Education Program Evaluation. R package version 2.4.1. https://CRAN.R-project.org/package=rcompanion

Martiny, J., Bohannan, B., Brown, J. H., Colwell, R. K., Fuhrman, J., Green, J., ... Staley, J. T. (2006). Microbial biogeography: putting microorganisms on the map. Nature Reviews Microbiology, 4, 102-112. https://doi.org/10.1038/nrmicro1341

Matsubara, T., Sugimori, F., Iwabuchi, K., \& Aoyama, K. (1994). The relation between the feeding activity of wintering shovelers (Anas clypeata) and the horizontal distribution of zooplankton in Lake Teganuma, Japan. Hydrobiologia, 294, 253-261. https://doi.org/10.1007/BF00021298

McGlinn, D., Xiao, X., McGill, B., May, F., Engel, T., Oliver, C., ... Chase, J. (2021). mobr: Measurement of Biodiversity. $\mathrm{R}$ package version 2.0.2. https://CRAN.Rproject.org/package $=$ mobr

McKay, H., Watola, G. V., Langton, S. D., \& Langton, S. A. (2006). The use of agricultural fields by re-established greylag geese (Anser anser) in England: A risk assessment. Crop Protection, 25(9), 996-1003. https://doi.org/10.1016/j.cropro.2006.01.010

Middleton, B. A., \& van der Valk, A. G. (1987). The food habits of greylag and barheaded geese in the Keoladeo National Park, India. Wildfowl, 38, 94-102.

Mony, C., Vandenkoornhuyse, P., Bohannan, B. J. M., Peay, K., \& Leibold, M. A. (2020). A landscape of opportunities for microbial ecology research. Frontiers in Microbiology, 11, 561427. https://doi.org/10.3389/fmicb.2020.561427

Nilsson, L., \& Persson, H. (1992). Feeding areas and local movement patterns of post-breeding Greylag Geese Anser anser in South Sweden. Ornis Svecica, 2, 77-90.

Ogle, D. H., Wheeler, P., \& Dinno, A. (2020). FSA: Fisheries Stock Analysis. R package version 0.8.31. https://github.com/droglenc/FSA

Oksanen, J., Blanchet, F. G., Friendly, M., Kindt, R., Legendre, P., McGlinn, D., ... Wagner, H. (2020). vegan: Community Ecology Package. R package version 2.5-7. https://CRAN.Rproject.org/package $=$ vegan

Oláh, J. Ifj. (2003). Vízimadár anyagforgalmi guildek. Magyar Vízivad Közlemények, 10, 381423.

Parada, A. E., Needham, D. M., \& Fuhrman, J. A. (2016). Every base matters: Assessing small subunit rRNA primers for marine microbiomes with mock communities, time series and global field samples. Environmental Microbiology, 18(5), 1403-1414. https://doi.org/10.1111/14622920.13023

Potts, M. (1999). Mechanisms of desiccation tolerance in cyanobacteria. European Journal of Phycology, 34, 319-328. https://doi.org/10.1080/09670269910001736382 
Ptacnik, R., Andersen, T., Brettum, P., Lepistö, L., \& Willén, E. (2010). Regional species pools control community saturation in lake phytoplankton. Proceedings of the Royal Society B: Biological Sciences, 277(1701), 3755-3764. https://doi.org/10.1098/rspb.2010.1158

Quast, C., Pruesse, E., Yilmaz, P., Gerken, J., Schweer, T., Yarza, P., ... Glöckner, F. O. (2013). The Silva ribosomal RNA gene database project: improved data processing and web-based tools. Nucleic Acids Research, 41, D590-6. https://doi.org/10.1093/nar/gks1219

R Core Team (2020). R: A language and environment for statistical computing. R Foundation for Statistical Computing, Vienna, Austria. https://www.R-project.org/

Rainey, F. A., Ray, K., Ferreira, M., Gatz, B. Z., Nobre, M. F., Bagaley, D., ... da Costa, M. S. (2005). Extensive diversity of ionizing-radiation-resistant bacteria recovered from Sonoran Desert soil and description of nine new species of the genus Deinococcus obtained from a single soil sample. Applied and Environmental Microbiology, 71, 5225-5235. https://doi.org/10.1128/AEM.71.9.5225-5235.2005

Ray, J. L., Althammer, J., Skaar, K. S., Simonelli, P., Larsen, A., Stoecker, D., ... Troedsson, C. (2016). Metabarcoding and metabolome analyses of copepod grazing reveal feeding preference and linkage to metabolite classes in dynamic microbial plankton communities. Molecular Ecology, 25, 5585-5602. https://doi.org/10.1111/mec.13844

Reise, K., Gollasch, S., \& Wolff, W. J. (1999). Introduced marine species of the North Sea coasts. Helgoländer Meeresuntersuchungen, 52, 219-234. https://doi.org/10.1007/BF02908898

Reynolds, C., \& Cumming, G. S. (2016). Seed dispersal by waterbirds in southern Africa: comparing the roles of ectozoochory and endozoochory. Freshwater Biology, 61(4), 349-361. https://doi.org/10.1111/fwb.12709

Rohwer, R. R., Hamilton, J. J., Newton, R. J., \& McMahon, K. D. (2018). TaxAss: leveraging a custom freshwater database achieves fine-scale taxonomic resolution. mSphere, 3(5), e0032718. https://doi.org/10.1128/mSphere.00327-18

Ruiz, G., Rawlings, T. K., Dobbs, F. C., Drake, L. A., Mullady, T., Huq, A., \& Colwell, R. R. (2000). Global spread of microorganisms by ships. Nature, 40, 49-50. https://doi.org/10.1038/35040695

Sánchez, M. I., Hortas, F., Figuerola, J., \& Green, A. J. (2012). Comparing the potential for dispersal via waterbirds of a native and an invasive brine shrimp. Freshwater Biology, 57(9), 1896-1903. https://doi.org/10.1111/j.1365-2427.2012.02852.x

Schloss, P. D., Westcott, S. L., Ryabin, T., Hall, J. R., Hartmann, M., Hollister, E. B., .. Weber, C. F. (2009). Introducing mothur: open-source, platform-independent, community supported software for describing and comparing microbial communities. Applied and Environmental Microbiology, 75(23), 7537-41. https://doi.org/10.1128/AEM.01541-09

Sharma, N. K., Rai, A. K., Singh, S., \& Brown, R. M., Jr. (2007). Airborne algae: their present status and relevance. Journal of Phycology, 43, 615-627. https://doi.org/10.1111/j.15298817.2007.00373.x

Schleper, C., Piihler, G., Kuhlmorgen, B., \& Zillig, W. (1995). Life at extremely low pH. Nature, 375(6534), 741-742. https://doi.org/10.1038/375741b0 
Silva, G. G., Green, A. J., Weber, V., Hoffmann, P., Lovas-Kiss, Á., Stenert, C., \& Maltchik, L. (2018). Whole angiosperms Wolffia columbiana disperse by gut passage through wildfowl in South America. Biology Letters, 14, 20180703. https://doi.org/10.1098/rsbl.2018.0703

Silva, G. G., Weber, V., Green, A. J., Hoffmann, P., Silva, V. S., Volcan, M., .. Maltchik, L. (2019). Killifish eggs can disperse via gut passage through waterfowl. Ecology, 100, e02774. https://doi.org/10.1002/ecy.2774

Sinclair, L., Osman, O. A., Bertilsson, S., \& Eiler, A. (2015). Microbial community composition and diversity via $16 \mathrm{~S}$ rRNA gene amplicons: evaluating the illumina platform. PloS One, 10(2), e0116955. https://doi.org/10.1371/journal.pone.0116955

Steiner, W., \& Parz-Gollner, R. (2003). Actual numbers and effects of recreational disturbance on the distribution and behaviour of greylag geese (Anser anser) in the Neusiedler See Seewinkel National Park Area. Journal for Nature Conservation, 11(4), 324-330. https://doi.org/10.1078/1617-1381-00064

Sterbetz, I. (1992). A Balatonon telelő északi vadlúdtömegek exkretumprodukciója. Aquila, 99, 33-40.

Szabó, A., Korponai, K., Kerepesi, C., Somogyi, B., Vörös, L., Bartha, D., ... Felföldi, T. (2017). Soda pans of the Pannonian steppe harbor unique bacterial communities adapted to multiple extreme conditions. Extremophiles, 21(3), 639-649. https://doi.org/10.1007/s00792017-0932-4

Szabó, A., Korponai, K., Somogyi, B., Vajna, B., Vörös, L., Horváth, Z., ... Felföldi, T. (2020). Grazing pressure-induced shift in planktonic bacterial communities with the dominance of acIII-A1 actinobacterial lineage in soda pans. Scientific Reports, 10(1), 1-12. https://doi.org/10.1038/s41598-020-76822-8

Telford, R. J., Vandvik, V., \& Birks, H. J. (2006). Dispersal limitations matter for microbial morphospecies. Science, 312(5776), 1015. https://doi.org/10.1126/science.1125669

Tóth, A., Horváth, Z., Vad, C. F., Zsuga, K., Nagy, S. A., \& Boros, E. (2014). Zooplankton of the European soda pans: Fauna and conservation of a unique habitat type. International Review of Hydrobiology, 99(3), 255-276. https://doi.org/10.1002/iroh.201301646

Valls, L., Castillo-Escrivà, A., Barrera, L., Gómez, E., Gil-Delgado, J. A., Mesquita-Joanes, F., \& Armengol, X. (2017). Differential endozoochory of aquatic invertebrates by two duck species in shallow lakes. Acta Oecologica, 80, 39-46. https://doi.org/10.1016/j.actao.2017.03.003

van der Gast, C. J. (2015). Microbial biogeography: the end of the ubiquitous dispersal hypothesis? Environmental Microbiology, 17(3), 544-546. https://doi.org/10.1111/14622920.12635

Viana, D. S., Santamaría, L., Michot, T. C., \& Figuerola, J. (2013a). Allometric scaling of longdistance seed dispersal by migratory birds. The American Naturalist, 181(5), 649-662. https://doi.org/10.1086/670025

Viana, D. S., Santamaría, L., Michot, T. C., \& Figuerola, J. (2013b). Migratory strategies of waterbirds shape the continental-scale dispersal of aquatic organisms. Ecography, 36(4), 430 438. https://doi.org/10.1111/j.1600-0587.2012.07588.x 
Viana, D. S., Santamaría, L., \& Figuerola, J. (2016). Migratory birds as global dispersal vectors. Trends in Ecology \& Evolution, 31(10), 763-775. https://doi.org/10.1016/j.tree.2016.07.005

Vyverman, W., Verleyen, E., Sabbe, K., Vanhoutte, K., Sterken, M., Hodgson, D. A., ... Wever, A. D. (2007). Historical processes constrain patterns in global diatom diversity. Ecology, 88(8), 1924-1931. https://doi.org/10.1890/06-1564.1

Wohl, D. L., Arora, S., \& Gladstone, J. R. (2004). Functional redundancy supports biodiversity and ecosystem function in a closed and constant environment. Ecology, 85(6), 1534-1540. https://doi.org/10.1890/03-3050

Zinger, L., Boetius, A., \& Ramette, A. (2014). Bacterial taxa-area and distance-decay relationships in marine environments. Molecular Ecology, 23, 954-964. https://doi.org/10.1111/mec.12640

Zobel, M., Öpik, M., Moora, M., \& Pärtel, M. (2006). Biodiversity and ecosystem functioning: It's time for dispersal experiments. Journal of Vegetation Science, 17, 543-547. https://doi.org/10.1111/j.1654-1103.2006.tb02477.x 


\section{Biosketch}

Beáta Szabó is a postdoc researcher at Institute of Aquatic Ecology, Centre for Ecological Research and interested in the processes underlying the formation of biodiversity and metacommunities of aquatic microorganisms with a special focus on small temporary ponds.

\section{Author contributions}

$\mathrm{ZH}, \mathrm{CFV}$ and RP conceived the ideas; $\mathrm{ZH}, \mathrm{CFV}, \mathrm{EB}$ and DL collected the samples; ZM performed the lab work; AS and ZM analysed the molecular data; BS and ZH performed the statistical analyses; BS wrote the manuscript with significant contributions by $\mathrm{ZH}, \mathrm{AS}$ and $\mathrm{CFV}$; all authors commented on earlier versions of the manuscript.

\section{Supporting information}

Additional supporting information may be found in the online version of the article at the publisher's website. 